\title{
"Det är klart de vet vad uppgivenhet betyder": Kommunikation och språk i vård- och omsorgsutbildning på komvux
}

\author{
('Of course they know what resignation means': \\ Communication and language in adult care education) \\ Sara Hultqvist \& Katarina Hollertz
}

Göteborgs universitet, Sverige (sara.hultqvist@socwork.gu.se)

\begin{abstract}
This article concerns the role of teachers as street level bureaucrats in Swedish vocational healthcare education for adult students. At the centre of the analysis are the challenges related to policy implementation when many of the students are second language speakers and language and communication play a role. Policy documents provide the analysis with a normative framework. Interviews with teachers give the analysis its standpoint. As a societal context, the field of elderly care suffers from labour shortages with difficulties recruiting trained staff. Policy stakeholders place high expectation on adult care education to both supply the labour market with trained staff, and to contribute to a smooth integration of migrants into society. As a matter of fact, half of the students in Swedish adult vocational healthcare education are migrants and the majority of those who complete the education get employment within elderly care. Thus, healthcare teachers are incremental to the implementation of policies. In their role as street level bureaucrats, they use different strategies to handle the press transferring sometimes contradictory policies into practice in the direct encounters with students. The results stress the importance of communication and language in healthcare education - and in elderly care practice.
\end{abstract}

Keywords: vocational education, language, communication, teachers, elderly care, Sweden 


\section{Inledning}

Den här artikeln handlar om lärarnas roll i svensk vuxenutbildning inriktad mot vård- och omsorgsarbete. I centrum för analysen står de utmaningar lärarna har att hantera ifråga om språk och kommunikation, när många av eleverna är andraspråkstalare. Med stöd i Michael Lipskys (2010) teori om gräsrotsbyråkrater och Evelyn Brodkins utveckling av samma idéer (2011), menar vi att lärarna i sina roller är utförare av statligt formulerad utbildnings- och socialpolitik och därmed kan kategoriseras som street level bureacrats, eller gräsrotsbyråkrater. Denna roll innebär en rad olika, ibland motstridiga, förväntningar. De ska bidra till samhällelig delaktighet för (ofta nyblivna) medborgare samtidigt som de ska följa läroplaner och detaljerade kursplaner och förse arbetsmarknaden med kompetent arbetskraft. För att placera texten i ett sammanhang presenterar vi inledningsvis vår ingång i ämnet. Vi diskuterar därefter förutsättningarna för vård- och omsorgsutbildning inom kommunal vuxenutbildning (komvux) i Sverige idag och beskriver vad som kännetecknar gruppen vuxenelever där.

Som ett ramverk för vår analys redogör vi för aktuell policy på området - den policy som lärarna i egenskap av gräsrotsbyråkrater översätter från policy till praktik - för att därefter låta komvuxlärare som undervisar på vård- och omsorgsutbildningar komma till tals. I fokus för analysen står deras yrkesvardag när de undervisar i klasser där flera elever har ett annat modersmål än svenska. Syftet är att undersöka lärarnas roll som gräsrotsbyråkrater och utmaningar de ser i relation till kraven på språk och kommunikation inom vård och omsorgsutbildning. Följande frågeställningar besvaras:

- Vilka normativa ramar återfinns i aktuell statlig policy på området som påverkar lärarnas arbete?

- Vilken roll spelar, enligt lärarna, språk och kommunikation på vård- och omsorgsutbildning inom komvux?

- Vilka utmaningar ser lärare i vård och omsorg i relation till språk och kommunikation hos eleverna?

- Hur hanterar lärarna i rollen som gräsrotsbyråkrater utmaningarna kopplade till språk och kommunikation?

Komvux har förutsättningar - och krav på sig - att skräddarsy och skapa utbildningar som svarar mot den lokala arbetsmarknadens behov. I artikeln ger vi konkreta exempel på hur språk och kommunikation fått en framträdande roll i vårdoch omsorgsutbildningar i Sverige idag. Det rör sig om aspekter som tidigare tagits för givna, men som på senare år diskuterats i såväl den politiska debatten som i omsorgspraktiken, som att lärare och elever kan prata med varandra och räkna med att göra sig förstådda samt att elever och lärare har ett gemensamt skriftspråk. Nedan följer en bakgrundsbeskrivning av forskningsprojektet som 
artikeln är sprungen ur, och av komvux som samhällsinstitution. Därefter presenterar vi teori, metod och material. Resultatredovisningen bygger på en genomgång av aktuell policy, normer och politiska propåer som stakar ut riktningen men också sätter gränser för lärarnas handlingsutrymme, och intervjuer med lärare, där de beskriver hur de ser på utmaningar förknippade med språk och kommunikation inom ramen för yrkesutbildning. I analysen och den avslutande diskussionen pekar vi på lärarnas förståelse och hantering av elevers utmaningar kopplade till talat och skrivet språk.

\section{Yrkesutbildning som socialpolitik, vår ingång till studien}

Under 2018 genomförde vi en studie om lokal arbetsmarknadspolitik i Göteborgs stad. "Det stegvisa jobb- och kunskapslyftet" var en kommunal satsning där personer utan sysselsättning men med försörjningsstöd erbjöds en ettårig anställning i kombination med utbildning. Satsningen bestod av parallella utbildningsspår som riktades mot branscher med personalbrist. Vi valde att undersöka spåret som var inriktat mot äldreomsorgen. Serviceassistent var yrkestiteln kopplad till inriktningen. I beskrivningen av en serviceassistents arbetsuppgifter ingick städ, sysslor i samband med måltider och andra servicetjänster i den kommunala äldreomsorgen. De skulle med andra ord avlasta undersköterskorna på stadens äldreboenden. Syftet med utbildningen till serviceassistent var dubbelt; dels att förse äldreomsorgen i Göteborgs stad med personal, dels att minska andelen arbetslösa personer som uppbar försörjningsstöd (Hultqvist \& Hollertz, 2021). Genom utbildningen och anställningen skulle dessa istället få lön, och så småningom också förhoppningsvis en anställning. Utbildningen innebar två dagars undervisning i skolan, följt av tre dagars arbete på något av stadens äldreboenden under ett års tid. I "Det stegvisa jobb- och kunskapslyftet" fanns ambitioner om att serviceassistenterna skulle fortsätta vidareutbilda sig till undersköterskor, efter avklarad utbildning till serviceassistent. Satsningen var därför tänkt att på kort sikt avlasta undersköterskor på äldreboenden i staden och på lång sikt förse äldreomsorgen med kvalificerad personal. Ungefär hälften av de deltagare som följde utbildningen till serviceassistent hade inte svenska som modersmål och fick extra språkstöd under utbildningen. Flera, såväl svenskfödda som utlandsfödda, hade dåliga erfarenheter av tidigare skolgång.

Vår ingång i den undersökningen var arbetsmarknadspolitisk. Som socionomer och forskare i socialt arbete hade vi båda erfarenhet av att studera samhällets åtgärder för att hantera sociala problem, exempelvis arbetslöshet. Tidigare forskning har beskrivit yrkesläraren som en förmedlare (Wärvik \& Lindberg, 2018); en mäklarroll som kopplar samman utbildning och arbetsliv. Samtidigt har förhållandet mellan lärande i klassrummet och det arbetsplatsförlagda lärandet visat sig innehålla flera utmaningar. De integrationspolitiska ambitionerna om att andraspråktalare snabbare ska lära sig svenska genom att delar av 
språkutbildningen förläggs till en arbetsplats har inte alltid infriats i verkligheten (Sandwall, 2013). I övrigt har yrkeslärares undervisningsvardag, i synnerhet på komvux, beskrivits som underbeforskad (Eliasson \& Rehn, 2017). Svensk arbetsmarknadspolitik och svensk utbildningspolitik är sedan 1950-talet delvis sammanflätade. Arbetsmarknadsutbildning har, jämte subventionerad sysselsättning och arbetsförmedling, varit en central beståndsdel i den aktiva arbetsmarknadspolitiken (Forslund \& Vikström, 2011) som den tog form efter andra världskriget (Petersson, 2009). Arbetsmarknadspolitiken har i sin tur tydliga socialpolitiska ambitioner. Den samtida kommunala trenden som går ut på att fusionera vuxenutbildning med delar av socialtjänsten till en samlad förvaltning har med andra ord historiska rötter. Bortser vi från de akademiska och professionella skiljelinjerna och betraktar kommunal verksamhet idag så är aktiviteter som kombinerar tre kommunala uppdrag - svenskundervisning för invandrare, vuxenutbildning och arbetsmarknadsåtgärder - inte något ovanligt (jfr Hamberg, 2015; Sarstrand Marekovic, 2011).

En av de viktigaste slutsatserna i rapporten "Lokal arbetsmarknadspolitik med fokus på autonomi och delaktighet: Ett brukarperspektiv på Det stegvisa jobb- och kunskapslyftet" (Hultqvist \& Hollertz, 2019) var att det saknades en struktur för stöd för deltagarna. Eftersom deltagarna befann sig i problematiska livssituationer, och i stor utsträckning saknade kunskap om det svenska välfärdssystemet och svensk arbetsmarknad, tvingades lärarna ta ett stort ansvar för information och vägledning - ett ansvar som sträckte sig långt utanför deras egentliga uppdrag som pedagoger. Gränsdragningen mellan reguljär utbildning och riktad arbetsmarknadsinsats väckte vår nyfikenhet och inspirerade oss till perspektivskifte. Vad skulle hända om vi betraktade studieobjektet först och främst som utbildning och inte som en arbetsmarknadsinsats? Denna fråga var vägledande när vi designade metodologin för den undersökning som utgör basen för analysen i artikeln. Här handlar det om lärarnas perspektiv, upplevelser och insikter i relation till betydelsen av språk och kommunikation inom ramen för vård- och omsorgsutbildning på komvux. Innan vi återkommer till det ska vi först ringa in vårt nyfunna problemområde (Smith, 2005, s. 206) och sätta det i ett sammanhang.

\section{Komvux, vård- och omsorgsutbildning och människorna där}

När vi skriver problemområde refererar vi till Dorothy Smith och institutionell etnografi (Smith, 2005). Vårt problemområde är utbildningsvardagen på komvux med inriktning mot vård och omsorg, där många elever har ett annat modersmål än svenska. Frågorna är sprungna ur faktiska erfarenheter snarare än ur teori det betyder att praktiken och de erfarenheter som görs där blir utgångspunkt för 
forskningen (jfr Smith, 2005). Vad som drivit oss mot komvux, vård- och omsorgsutbildning och dess lärare är frågor som väckts under tidigare genomförd forskning med fokus på arbetsmarknadspolitik.

Komvux omfattar fler elever än gymnasieskolan (Fejes, 2019) och har sedan 2012 sin egen läroplan. Den rymmer skolformerna svenska för invandrare, kommunal vuxenutbildning på grundläggande nivå och på gymnasial nivå. Som utbildningsverksamhet har komvux expanderat kraftigt. Elevgruppen är heterogen med en stor andel elever födda utomlands och många elever med olika former av funktionsnedsättning. Som konsekvens ställs höga krav på att undervisningen ska vara flexibel. Bland de olika yrkesinriktningarna på komvux är vård och omsorg den vanligaste (Skolverket, 2019). Den yrkestitel som är målet för de allra flesta som läser vård- och omsorgskurser på komvux är undersköterska. Under 2018 läste cirka 16000 komvuxelever inriktning vård och omsorg (Skolverket, 2019). Av dessa var hälften födda i ett annat land än Sverige (Skolverket, 2020).

Sedan hösten 2015 har flera nationella förändringar gjorts i syfte att korta vägen till nyanländas självförsörjning (Dahlström \& Gannå, 2017). På många håll i landet ges yrkes-sfi-utbildningar och kombinationspaket till arbeten inom bristyrken. Nationellt centrum för svenska som andraspråk poängterar vikten av att utbildningarna ges integrerat med en samordning av kurserna, snarare än parallellt. Utbildningsplikten som infördes 2018 ger nyanlända elever rätt och skyldighet till kombinerade heltidsstudier under etableringsperioden (Dahlström \& Gannå, 2017). När det gäller yrkeslärarna på vård- och omsorgsutbildningar på komvux är de allra flesta utbildade sjuksköterskor i grunden. Yrket vårdlärare är sprunget ur behovet att bemanna lärartjänsterna vid sjuksköterskeutbildningarna i landet. Sedan 1970-talet kan också arbetsterapeuter, fysioterapeuter och socionomer bli vårdlärare och i och med 2011 års lärarutbildningsreform ökade möjligheten för undersköterskor att bli vårdlärare (Eliasson \& Rehn, 2017). Fortfarande är emellertid de flesta vårdlärare sjuksköterskor som kompletterat med en yrkeslärarutbildning som omfattar 90 högskolepoäng. Att vårdläraryrket har så intima band till sjuksköterskeyrket är värt att notera i ljuset av att yrkeslärare, för att kunna arbeta i enlighet med fastställd läroplan är beroende av "praktiken", den arbetsplatsförlagda delen av utbildningen (APL). När eleverna gör APL i äldreomsorgen är det undersköterskorna som agerar handledare och på en daglig basis guidar eleverna i lärandet (Wärvik \& Lindberg, 2018). Det är med andra ord en arena där lärarna själva inte deltar, och där det finns en betydande statushierarki mellan olika yrkeskategorier. Sjuksköterskorna är exempelvis tydligt överordnade undersköterskorna.

Ovanstående ger en övergripande, nationell bakgrund till vårt problemområde. Med denna fond är det viktigt att påminna om att sfi och komvux är just kommunala angelägenheter $\mathrm{i}$ ett land med långtgående kommunalt självstyre (Andrén, 2007) och där privatiseringen av kommunal utbildning i delar av landet är omfattande (Dahlstedt \& Fejes, 2019). Vårt problemområde formulerades med 
utgångspunkt i en studie av en lokal arbetsmarknadsinsats där en särskild bransch, nämligen äldreomsorgen, varit ständigt närvarande diskussionerna. Äldreomsorgen är också det vanligaste arbetsfältet för de som utbildar sig till undersköterska i Sverige. Faktum är att undersköterska inom äldreomsorgen är Sveriges vanligaste yrke. Dessutom är det ett yrke som nästan uteslutande utövas av kvinnor, knappt en av tio är män (SCB, 2020b). Inom äldreomsorgsforskningen har lokala variationer och när skillnader ska betraktas som problem lyfts fram som ett underbeforskat område (Jönson \& Szehebely, 2018). Det kommunala självstyrets konsekvenser för vård- och omsorgsutbildning vid komvux framstår i analogi med dess konsekvenser för äldreomsorgen som ett angeläget ämne att studera. Skiftande kommunala förutsättningar för komvux är tillsammans med de lokala variationerna i äldreomsorgen förhållanden som talar för att framtida forskning tar ett helhetsgrepp om frågor som rör sfi, vård- och omsorgsutbildning på komvux och arbetsmarknadsinsatser.

\section{Teoretisk utgångspunkt}

Med vårt teoretiska raster lånat från Michael Lipsky (2010) betraktar vi komvuxlärarna som utförare av statligt formulerad utbildnings- och socialpolitik. Det innebär att deras roll är att omsätta policy till praktik. De förväntas agera i enlighet med Skolverkets styrdokument, i sin undervisning följa läroplaner och stötta elever i att nå kursplanemål. De förväntas också i sin yrkesgärning bidra till att socialpolitiska mål om arbetsmarknadsdeltagande och integration av invandrare nås. Komvuxlärarna befinner sig i ett korsdrag där de i sin yrkesvardag möter skilda och ibland motstridiga krav. Å ena sidan har de att leva upp till statsmakternas krav och förväntningar på kvalitet beträffande innehåll i undervisningen. $\AA ̊$ andra sidan finns elevernas krav och förväntningar på utbildningen, som i sin tur påverkas av deras unika livssituation; inte minst tillgång till språk och förutsättningar för kommunikation. Lärare kan som en av flera välfärdsprofessioner karakteriseras som gräsrotsbyråkrater (Lipsky, 2010). Kännetecknande för gräsrotsbyråkrater är att de i sin yrkesvardag måste hantera såväl statsnyttiga som individfokuserade mål (jfr Lipsky, 2010). För lärarna i den organisatoriska kontext där de befann sig i den här studien, kommunal vuxenutbildning, gällde det att kunna möta olika behov i en heterogen elevgrupp så att var och en som avslutade utbildningen gjorde det med godkända betyg och en känsla av att vara redo för yrkesarbete. Elevernas krav och förväntningar handlade om att kunna ta del av en utbildning där de förstod innehållet, där de hade förutsättningar att själva göra sig förstådda och att bli rustade inför ett inträde på arbetsmarknaden. Lärarna befann sig vidare i en position där utbildningsanordnaren (den egna skolan) ofta sammanföll med den presumtiva arbetsgivaren (äldreomsorgen), eftersom båda verksamheterna drevs i kommunal regi. Kommunen som huvudman för skolan ställde krav på läraren att läroplanen skulle följas. Kommunen 
som huvudman för äldreomsorgen förväntade sig att lärarna examinerade kompetenta undersköterskor på så kort tid som möjligt för att säkerställa bemanningen. Med andra ord var det interna, kommunala trycket på lärarna dubbelt, å ena sidan från kommunen som utbildningsanordnare, å andra sidan från kommunen som framtida arbetsgivare för undervisade elever. Till detta dubbla kommunala tryck kom dessutom statliga socialpolitiska krav på vad komvuxutbildning ska bidra med i termer av samhällelig delaktighet och arbetsmarknadsdeltagande. Det kom an på den enskilda läraren att i utbildningsvardagen ständigt balansera dessa, ibland motstridiga, krav.

\section{Metod och material}

Vi har använt två sorters empiriskt material för att undersöka lärarnas roll som gräsrotsbyråkrater och utmaningar de ser i relation till kraven på språk och kommunikation inom vård- och omsorgsutbildning. För det första har vi undersökt offentligt tryck från två relevanta statliga utredningar, och för det andra har vi genomfört intervjuer med lärare. Intervjuerna med lärare har gett oss en utkiksplats, en subjektsposition från vilken vi närmat oss problemområdet (Smith, 2005, s. 10). Offentligt tryck, publikationer från statliga utredningar, representerar det institutionella ramverket för den utbildningsvardag vi beforskar. Publikationerna ger uttryck för normer och värderingar som styr denna institutionella praktik (jfr Norstedt, 2011). På så sätt har den institutionella etnografin väglett oss i valet av empiri. Också Michael Lipskys (2010) och Evelyn Brodkins (2011) idéer om gräsrotsbyråkrater har påverkat empirivalet och format analysen. Det är först när styrdokument blir till konkreta handlingar som politiken kan utvärderas (jfr Brodkin 2011; Weatherly \& Lipsky, 1977). Lärarna är centrala aktörer för att implementera politiken och blir därmed gräsrotsbyråkrater i dessa praktiker.

I den här studien görs nedslag i två svenska kommuner. Vårt val att intervjua lärare i två olika kommuner var betingat av att komvuxutbildningen ser olika ut i olika kommuner. Vi ville undvika att de lärarintervjuer som utgjorde bas för vår analys representerade en ytterlighet, något ovanligt. De två kommuner där de intervjuade lärarna är verksamma skiljer sig åt på flera sätt. Göteborg är landets näst största kommun med drygt en halv miljon invånare. Den lilla kommunen har ett invånarantal på drygt 12 000. I Göteborg är medelåldern lägre och andelen högskoleutbildade fler än i den lilla kommunen (SCB, 2020a).

Materialinsamlingen bestod av fyra faser. I den första fasen träffade en av författarna (Sara) lärare, rektor och socialnämndens ordförande i den mindre kommunen ${ }^{1}$ och presenterade resultatet från undersökningen av Det stegvisa jobboch kunskapslyftet. Vi diskuterade då var tonvikten skulle ligga i en framtida gemensam studie och enades om att språk och kommunikation var ämnen som vi tillsammans ville fördjupa oss i, i relation till utbildningsvardagen på komvux. 
I fas två intervjuade vi individuellt fyra komvuxlärare som arbetade med att utbilda undersköterskor. Två av lärarna arbetade i Göteborg och två i den lilla kommunen. Intervjuerna spelades in, transkriberades och tematiserades (Braun \& Clarke, 2012). I vår hantering av materialet har vi snarare haft ett realistiskt än diskursivt tillnärmelsesätt (Braun \& Clarke, 2020), trots att det övergripande temat varit språk och kommunikation. Analysen är också starkt färgad av att vi haft arbetsmarknadspolitik och kopplingen till äldreomsorgen som troligt framtida yrkesfält i fokus, snarare än tankemodeller och erfarenheter rotade i utbildningsvetenskap. Varje intervju varade mellan en och två timmar, och genomfördes på lärarnas respektive arbetsplatser. En av de intervjuade lärarna i Göteborg, Britta, var sfi-lärare med erfarenhet av att undervisa i yrkessvenska. Fanny, Jana och Therese var vårdlärare, i botten sjuksköterskor med en avslutad eller pågående yrkeslärarutbildning. ${ }^{2}$ Med andra ord representerade de med sin kliniska bakgrund majoriteten av yrkeskåren vårdlärare.

Den tredje fasen i materialinsamlingen bestod av en genomgång av aktuella policydokument på området. Här framträdde två pågående statliga utredningar som särskilt centrala. Den första var utredningen om reglering av yrket undersköterska (dir. 2017:03) och den andra var utredningen för stärkt kvalitet och likvärdighet inom komvux för elever med svenska som andraspråk (dir. 2018:06). Offentligt tryck publicerat inom ramen för dessa utredningar har fungerat som nav i vår undersökning av statlig, aktuell policy på området.

Den fjärde fasen bestod av en workshop till vilken samtliga intervjuade lärare var inbjudna. ${ }^{3}$ I slutändan deltog två, varav en som inte hade intervjuats men som arbetade i den lilla kommunen. I denna diskuterades den tentativa kodningen som hade gjorts med utgångspunkt från intervjuerna. Det var med andra ord en process där våra analyser utvecklades gemensamt med lärarna, i en samskapande process. Workshopen pågick under en heldag. I efterhand kunde vi konstatera att mycket av tiden ägnades åt konkreta lärarerfarenheter relaterade till frågor som rörde språk och kommunikation. Workshopen bidrog på så sätt med exempel gentemot vilka vi kunde validera och revidera våra tentativa tolkningar av intervjuerna. Också frågor om villkor som påverkade lärarnas arbetsvardag, utan att direkt vara kopplad till lärarrollen, kom upp under workshopen. Exempel på sådana villkor var svensk migrationspolitik och arbetsplatskultur inom äldreomsorgen.

\section{Resultatframställning och analys}

\section{Arbetskraftsbrist och bristande kompetens bland undersköterskor}

Som gräsrotsbyråkrater verkar alltså lärarna inte bara i ett tvärdrag där de tvingas hantera krav från både statsmakternas sida och från elever. Som yrkeslärare på komvux befinner de sig på ett välfärdsstatligt område vars funktion är 
att rusta elever att bli självförsörjande och att förse arbetsmarknaden med kompetent personal. Detta ställer alldeles särskilda krav när arbetsmarknaden ifråga är vård och omsorg och när många av eleverna har ett annat modersmål än svenska. Aktuell statlig policy på området sätter de normativa ramarna för lärarnas undervisningsvardag och pekar också ut vad som anses vara brister och ouppnådda mål.

År 2019 presenterade den så kallade KLIVA-utredningen 4 promemorian "På väg - mot kvalitet och likvärdighet inom komvux för elever med svenska som andraspråk". Som en utgångspunkt framhölls att vuxenutbildningen inte bör reduceras till en arbetsmarknadspolitisk åtgärd (s. 12). Promemorian betonade vuxenutbildningens breda uppdrag och sfi-kursplanens skrivningar om utbildning för aktivt deltagande i samhällets olika fält: i samhälls-, vardags- och arbetsliv samt möjligheter till vidare studier. I KLIVA-utredningens slutbetänkande "Samverkande krafter - för stärkt kvalitet och likvärdighet inom komvux för elever med svenska som andraspråk" (SOU 2020:66) framhölls att bristande likvärdighet mellan olika kommuner är ett problem och att det generellt $i$ landet finns omfattande brister i kvalitet. Verksamheterna har begränsade förutsättningar för att utvecklas i samklang med forskning och beprövad erfarenhet och utifrån arbetsmarknadens och elevernas behov. Orsakerna beskrevs vara flera, men främst handlar det om otydligheter i och okunskap om gällande regleringar och gedigna beslutsunderlag såsom relevant forskning och dokumenterad beprövad erfarenhet samt tillförlitlig statistik och kunskap om elevernas tidigare kunskaper och erfarenheter. Att en stor andel av sfi-lärarna är obehöriga trots lågt ställda behörighetskrav var ett konkret problem som lyftes fram i slutbetänkandet.

Slutbetänkandet föreslog att komvuxutbildning framöver bör integreras i högre grad än idag. En integrerad utbildning innebär att lärandemål, kunskapskrav och innehåll i olika kurser ska förenas till en helhet för eleven. Kombinerade och integrerade utbildningar ger möjlighet att lära sig språk i ett meningsfullt och praktiskt sammanhang, något som stärker motivationen (SOU 2020:66, s. 114). Tanken på en sammankoppling av svenskundervisning och undervisning $i$ yrkesämnet, i det här fallet vård och omsorg, återfinns i både Det stegvisa jobboch kunskapslyftet i Göteborg och i sättet att bedriva kommunal vårdutbildning i den lilla kommunen.

I slutbetänkandet fördes ingen utförlig diskussion om huruvida de förlagsproducerade läromedel som finns att tillgå är ändamålsenliga. Däremot noterades att en kunskapsöversikt på området (Vetenskapsrådet, 2012) pekat på att det saknas forskning på detta område. Vidare, och av särskild betydelse för möjligheten till flexibel undervisning, i tider av pandemi, hävdades att arbetet med frågor som rör distansundervisning kan ha kommit i skymundan sedan myndigheten Nationellt centrum för flexibelt lärande avvecklades 2008 (SOU 2020:66, s. 258259). Valideringsfrågan diskuterades i såväl promemorian som slutbetänkandet, 
men här fanns också en separat delegation tillsatt (SOU 2019:69). Valideringsdelegationens förslag om en ny bestämmelse i skollagen i syfte att stärka elevens rätt att få sina kompetenser kartlagda inför sin utbildning backades upp av slutbetänkandet i KLIVA-utredningen (SOU 2020:66). Dels främjar en solid valideringsapparat enligt utredningen en ändamålsenlig studieplanering för eleven, dels kan resultaten av kartläggningarna användas i kommunernas arbete med att organisera utbildningsverksamheten. De diskussioner vi hade på våra workshops om svårigheterna med att få till stånd en validering av tidigare kunskap rimmar väl med resonemangen ovan. Däremot beskrev inte de lärare vi intervjuat att de själva saknade kompetens. Här spelade sannolikt urvalet in. Lärarna vi har talat med har samtliga ett specialintresse när det gäller andraspråksinlärning. En var utbildad ämneslärare i (flera främmande) språk, en hade flera modersmål, en var utbildad till språkombud och en hade läst främmande språk vid universitetet. Flera av dem hade erfarenhet av att ha levt i olika länder, i olika språkområden. Temat för studien, språk och kommunikation, hade vi tillsammans kommit överens om.

Frågan om det kommunala självstyret diskuterades också i utredningen och det konstaterades att kommunerna har olika förutsättningar att erbjuda ett för invånarna relevant kursutbud. Inte minst gällde detta skiftande ekonomiska villkor. Resursfördelningen till komvux prioriteras lokalt mycket olika och av den statliga schablonersättning som kommunerna tilldelas per nyanländ flykting använder olika kommuner olika stor andel till vuxenutbildningen, enligt utredningen. Ett av skälen till att vi valde att undersöka komvuxverksamhet i två kommuner var också de skilda försättningar som stora och små kommuner har att bedriva yrkesutbildning för vuxna.

Den andra av de statliga utredningar som vi menar har stor betydelse för att förstå den utbildningsvardag vi undersökt tillsattes av regeringen 2017 och hade till syfte att föreslå hur yrket undersköterska skulle kunna regleras för att öka kvaliteten och säkerheten inom vård och omsorg. Yrkeslärarnas position gör att de, till skillnad från ämneslärarna, har ett konkret yrkesfält och ett framtida yrke för sina elever att förhålla sig till. För vårdlärarnas del är en annan del av den egna organisationen (den egna kommunen), nämligen äldreomsorgen, den vanligaste arbetsgivaren för de elever som undervisas. Därmed uppstår en särskild relation där lärarna (ibland outtalat) har till uppgift att internt förse en annan del av den egna organisationen med arbetskraft.

2019 kom utredningen med betänkandet "Stärkt kompetens i vård och omsorg" (SOU 2019:20). Utbredda kompetensbrister lyftes då fram. Kompetensbristerna sågs som en konsekvens av att undersköterskeyrket hittills varit oreglerat, vilket i sin tur fått till följd att i princip vem som helst har kunnat anställas som undersköterska. En återkommande synpunkt bland de kommuner som tillfrågats i utredningen var att undersköterskor som genomgått vuxenutbildningen ofta 
inte har tillräckliga kunskaper i språk och i yrkesämnena. Samtidigt har personalförsörjning inom svensk äldreomsorg diskuterats som ett problem under minst ett par decennier. Läget 2020 framstår som påfallande likt det som rådde 2001 (Socialstyrelsen, 2004) och kan sammanfattas med att det saknas undersköterskor inom äldreomsorgen.

Kompetensbrist och personalbrist är med andra ord två stora utmaningar för äldreomsorgen. Rekrytering av personer med utländsk bakgrund som i närtid anlänt till Sverige och som söker ett yrke där man har kompetens från tidigare hemland eller vill skaffa sig yrkesutbildning för att få den kompetens som krävs för arbete som undersköterska, har specifikt framhållits som en möjlig politisk strategi för ökad rekrytering till yrkesutbildning och arbete som undersköterska (SOU 2017:21). En växande andel av de examinerade med vård- och omsorgsutbildning från komvux har också utländsk bakgrund (SOU 2017:21). De utbildningar vi har undersökt visar upp samma mönster. En stor andel av de vuxenstuderande på vård- och omsorgsutbildningarna i Göteborg och i den lilla kommunen hade utländsk bakgrund och ett annat modersmål än svenska.

De statliga lägesbeskrivning som speglats i de två utredningarna som refererats ovan ger en bild av nuläget inom komvux och den del av arbetsmarknaden som de allra flesta går till efter avslutad vård- och omsorgsutbildning vid komvux, nämligen äldreomsorgen. Utredningarna är också normerande i det att de stakar ut vägen mot politiskt uppsatta mål. Dessa mål finns med som ledstjärnor i reglerande texter på lägre nivåer, i kommunen, och styr på så vis riktningen på den verksamhet som är lärarnas yrkesvardag. Samtidigt kännetecknas lärarnas roll som gräsrotsbyråkrater av handlingsutrymme (Lipsky 2010; Weatherly \& Lipsky, 1977). Handlingsutrymmet är kringskuret av de organisatoriska resurserna och av lagar, förordningar och riktlinjer. Vanligen är efterfrågan på resurser större än utbudet. Det kommer an på gräsrotsbyråkraten att hantera glappet mellan behov av resurser och tillgång på resurser.

Problembeskrivningen rörande äldreomsorgen, att det råder personalbrist och kompetensbrist, framstår som tämligen konstant de senaste 15 åren. Däremot verkar det ha skett en förskjutning i kompetensdiskussionen. Idag är språk och kommunikation på ett helt annat vis än för 15 år sedan i fokus. Bristande språkkunskaper hos undersköterskor är ett problem som kommunerna som arbetsgivare uppmärksammat och som den statliga utredningen nu påpekar i förslaget om en reglerad underskötersketitel. Också i forskningen har språkets betydelse för omsorgsarbetet lyfts fram på senare år. I sin doktorsavhandling identifierade Palle Storm (2018) två undersökningsspår. Det ena behandlade personalens möjligheter att hjälpa äldre omsorgstagare som inte talar det nya hemlandets språk. Det andra spåret handlade om utmaningar som uppstår när omsorgspersonal inte behärskar majoritetsbefolkningens språk. Enni Paul (2017) undersökte skriftbruk bland vård- och omsorgselever på gymnasiet i sin doktorsavhandling. Hon konstaterade att samhället $\mathrm{i}$ allmänhet och arbetsmarknaden i synnerhet blir mer 
och mer skriftburet. Textualisering av arbetsplatser och arbetsuppgifter har ökat i linje med denna övergripande utveckling, vilket betytt att fler och fler handlingar i arbetet sker inbäddat i, i samspel med eller genom texter. Denna utveckling är en följd av högre krav på transparens, uppföljning och kontroll. Också digitalisering och nya rationalitetsnormer har gjort att text tillmäts allt större vikt (Paul, 2017). I den europeiska forskningen (Weinar m.fl., 2018) finns ett växande fält som behandlar frågor om hur migration, omsorgsarbete och socialpolitik hänger samman. Inte minst ställs frågor om migration som konsekvens av att arbetslösa får anställning i omsorgssektorn i ett annat land än det egna. I vår undersökning är relationen mellan migration, omsorgsarbete och socialpolitik en annan. De människor som läser vård och omsorg på komvux har ofta flyktingbakgrund. Däremot har de inte migrerat till Sverige för att arbeta i vård- och omsorgssektorn. Oavsett hur kopplingen mellan migration, omsorg och socialpolitik ser ut, verkar språk och kommunikation få en växande betydelse för omsorg, både som utbildnings- och som yrkesfält.

\section{Utbildningsvardagen på komvuxutbildning inriktad mot vård och omsorg}

I intervjuerna med lärare var vi särskilt nyfikna på lärarnas syn på sina förutsättningar att rusta eleverna till ett framtida yrkesliv inom äldreomsorgen, som är den del av arbetsmarknaden där de flesta som gått en vård- och omsorgsutbildning på komvux arbetar. Detta mot bakgrund av att en växande andel av de personer som arbetar inom svensk äldreomsorg har utländsk bakgrund och att statsmakterna har ställt stor tilltro till att personer som invandrat till Sverige på senare år ska utbilda sig inom vård och omsorg och därmed dämpa den växande bristen på personal inom äldreomsorgen. Valet att låna just vårdlärarnas utkikspunkt var betingat av vår syn på deras roll som gräsrotsbyråkrater: dels är de utbildare med lärandemål och kursplaner att förhålla sig till, dels förväntas de förse ett yrkesfält med arbetskraft. Genom sin position mellan politik och praktik har de en unik position att säga något om hur den tänkta politiken faller ut.

Få skillnader mellan resonemangen i Göteborg respektive den lilla kommunen rörande språkets roll på utbildningen framträdde. Resonemangen liknade varandra. Lärarna var till exempel eniga om att det fanns många fördelar med att blanda personer med olika bakgrund och olika modersmål i en och samma klass. Det berikade en undervisningssituation och gav upphov till dynamiska diskussioner. Samtidigt vållade alltför stora skillnader i språklig repertoar hos eleverna lätt irritation när vissa elever upplevde att de alltid var tvungna att vänta in och hjälpa till, medan andra ständigt kämpade med att förstå instruktioner och följa med i resonemang. I båda kommunerna framhölls också att språk är centralt på flera, olika sätt. Dels handlade det om att många som läser vård och omsorg har ett annat modersmål än svenska, dels om att det är vanligt med läsoch skrivsvårigheter bland eleverna. Också det faktum att många av eleverna har en brokig utbildningsbakgrund med skral kompetens i det egna modersmålet 
"Det är klart de vet vad uppgivenhet betyder"

(oavsett om det är svenska eller något annat) som följd, var en faktor som gjorde att språk fick en central betydelse i undervisningsvardagen. Att ha en akademisk utbildning sågs till exempel som en fördel, oavsett var i världen eleven utbildat sig. Samtidigt som alla var överens om att språk på olika vis var betydelsefullt i deras undervisningsvardag så påpekade en av lärarna, Therese, att utbildning generellt, snarare än konkreta svenskkunskaper, hade större betydelse för studieframgång på individnivå: "Enligt min erfarenhet så är utbildningsbakgrunden en viktigare faktor i utbildningssammanhang än bara själva språket i sig."

Ett tema som togs upp i den lilla kommunen var att möjligheten att organisera klasserna så att elever med vitt skilda svenskkunskaper inte hamnade i samma klass begränsades av ett tryck från skolledningens håll på att "fylla klasser". Pedagogiska utmaningar med heterogena undervisningsgrupper där elevernas svenskkunskaper skiljer sig åt mycket framträder sannolikt oftare i glest befolkade kommuner än i tätbefolkade. Också den splittring av vuxenutbildningen som privatisering av komvux har lett till bidrar sannolikt till att skapa konkurrenssituationer mellan utbildningsanordnare som leder till ökat tryck på att fylla upp klasser av ekonomiska skäl.

I sorteringen och tematiseringen av lärarintervjuerna utkristalliserade sig ett mönster i resonemangen om språk och kommunikation i utbildningsvardagen. Resonemangen kretsade kring problemsituationer och de handlade om att $t a$ in tal och text och att förmedla tal och text.

Tabell 1. Matris över problemsituationer.

\begin{tabular}{|l|l|l|}
\hline & Tal & Text \\
\hline Ta in & $\begin{array}{l}\text { Förstå muntliga instruktioner, i } \\
\text { klassrummet och i omsorgspraktiken }\end{array}$ & $\begin{array}{l}\text { Tillgodogöra sig det skrivna i } \\
\text { läromedel, i daganteckningar och } \\
\text { vårdplaneringar }\end{array}$ \\
\hline Förmedla & $\begin{array}{l}\text { Kunna ställa frågor och uttrycka } \\
\text { egna behov för att kunna lära in och } \\
\text { utföra ett gott omsorgsarbete }\end{array}$ & $\begin{array}{l}\text { Kunna uppvisa förvärvad kun- } \\
\text { skap i skriftliga prov och skriva } \\
\text { daganteckningar }\end{array}$ \\
\hline
\end{tabular}

Ta in tal och text

Jana fick en gång ett irriterat samtal från personal på en arbetsplats inom äldreomsorgen där en elev gjorde sin APL. Enligt personen som ringde kunde eleven inte göra en smörgås.

Bre en smörgås, gör så. Det är ju en elev du har med dig och det kanske du gör första gången ändå. Smörgåsen har man på smör och så ett pålägg, vad det är. Och jag tror ju inte han är dummare än att han förstår det då. 
Jana var kritisk till hur svårigheten hanterades på arbetsplatsen och menade att vissa saker går att lösa på plats. Jana tillade: "Men att man inte kan bre en macka för att man inte har hört ordet" och menade att personalen inom äldreomsorgen har ett ansvar att underlätta kommunikation när eleven har ett annat modersmål än svenska; det krävs inte särskilt mycket fantasi för att som handledare byta strategi när en elev inte förstår ett ord och istället för att säga "bre en smörgås" visa hur det går till att bre en smörgås. Hon avslutade resonemanget med att konstatera: "Nä det är lite onödigt bråk om småsaker."

Språkproblemet som Jana beskrev hänger samman med att handlingsförmåga inte alltid sammanfaller med förmågan att benämna saker och handlingar. För henne är det självklart att den här eleven kan göra en smörgås även om eleven inte kan orden och förstår innebörden av att "bre en smörgås". Att i den situationen göra frågan till ett problem istället för att pragmatiskt visa vad som avses är för Jana att skapa "onödigt bråk om småsaker". Även om eleven inte förstod innebörden i uppmaningen "bre en smörgås", så hade personalen kunnat kommunicera samma innebörd på annat sätt än språkligt, genom att visa. Jana menade att den här sortens hinder ofta är enkla att komma över, men då krävs god vilja från handledare i den arbetsplatsförlagda delen av utbildningen. Janas resonemang illustrerar att hennes möjligheter att som vårdlärare påverka lärosituationer i det arbetsplatsförlagda lärandet är begränsade (jfr Wärvik \& Lindberg, 2018).

På frågan om vad hon såg som den största språkrelaterade utmaningen för eleverna under utbildningen svarade en av lärarna, Fanny: "Ordförståelse av abstrakta ord och, ursäkta uttrycket, ordbajs som finns i våra läroböcker." Fanny var kritisk till utvecklingen av läromedel och menade att många av de ord som stod i böckerna var sådana som aldrig används och spekulerade i varför: "Man har gjort nya ord, för att som jag tror höja statusen."

Fanny menade att det hade varit "otroligt bra om någon ville titta på läroböckerna" och påpekade att det faktiskt finns synonymer i ett språk. Det finns sällan inte bara ett ord som är det gångbara. Det viktigaste är att förstå innebörden och det gör eleverna ofta även om de inte kan en särskild glosa, enligt Fanny. Hon illustrerade med ordet "uppgivenhet". Eleverna kanske inte kan den svenska glosan, men "Det är klart de vet vad uppgivenhet betyder". Det handlar, i Fannys perspektiv, om att språket måste anpassas så att det blir begripligt och ändamålsenligt för eleverna i utbildningsvardagen. Samtidigt lyftes flera gånger den svåra balansgången mellan att å ena sidan använda de facktermer som är gängse i vård- och omsorgsvardagen och å andra sida inte i onödan tala och skriva "tillkrånglat" i klassrumsundervisningen. Uttrycket "att göra nedre toalett" och orden "nutrition" och "elimination" exemplifierade denna balansgång - facktermer som betraktas som svåra men ändå viktiga att ha med sig in i yrket.

På olika sätt beskrev Jana och Fanny kommunikationsproblem som hade att göra med att ta in tal och text. Det rörde sig i smörgåsexemplet om klyftan mellan 
"Det är klart de vet vad uppgivenhet betyder"

att kunna utföra en uppgift och att kunna benämna och i kurslitteraturexemplet om en klyfta mellan att förstå innebörden av något abstrakt, exempelvis en känsla, och kunna benämna detsamma. Båda pekade på att dessa problem inte är omöjliga att lösa. Jana föreslog att pragmatiskt visa, använda andra kommunikationssätt, som komplement till att instruera med ord. Fanny hävdade att en översyn av läroböckerna beträffande vilka ord som används hade kunnat underlätta undervisningsvardagen.

\section{Förmedla tal och text}

Britta beskrev att den största utmaningen för henne som lärare var att förstå vad som ligger bakom att språket inte utvecklas hos en elev. "Den största utmaningen var att det var svårt att förstå när de inte lärde sig. Vad är det som ligger bakom det? Varför utvecklas inte språket hos den här personen?"

Att veta exakt vilken typ av stöd varje enskild elev behöver för att göra språkliga framsteg beskrevs som svårt, i synnerhet i heterogena elevgrupper där några elever hade svenska som modersmål och andra inte, och där erfarenheterna av tidigare studier skiljde sig mycket mellan eleverna. Saknade eleverna språklig repertoar för att uttrycka sina behov, att berätta för läraren när och hur något upplevdes som svårt, var det lätt att som lärare "tappa någon elev på vägen". Malin Dahlström och Lisa Gannå (2017) noterade i sin studie att de språkligt mest avancerade eleverna på en yrkesutbildning på komvux var de som tog och fick större delen av taltiden. I analogi med detta finns risken att de elever som enkelt kan formulera sig på svenska också är de som lägger an tonen i klassrummet. Britta förde också ett resonemang om hur skam var en stark drivkraft. Hon menade att många missförstånd hängde samman med att människor skäms för att fråga när de inte förstår. Utifrån ett sådant resonemang skulle modet att våga fråga kunna vara ett sätt att förhindra missförstånd. Att en bekräftande och trygg lärmiljö främjar språkinlärning stöttas av tidigare forskning av andraspråkstalande elever på komvux (Sandwall, 2013).

Therese beskrev hur tätt sammanflätade svenskkunskaperna och möjligheterna att lyckas på utbildningen var. Hon menade att för henne som yrkeslärare stod förvisso inte språket i fokus vid bedömning av inlämningstexter och skriftliga prov, men att förmågan att uttrycka sig väl i text på svenska ändå var en viktig faktor vid bedömning.

$$
\begin{aligned}
& \text {... det påverkar ju säkert både medvetet och omedvetet om någon har uttryckt sig } \\
& \text { ordentligt. Lay-outen och allting, det ska inte påverka, men det påverkar för jag făr } \\
& \text { ju ut mer om det är en välskriven text. Jag kan ju förstå elevens kunskaper på ett } \\
& \text { helt annat sätt să de har ju ett försprång de eleverna som kan uttrycka sig bra. De } \\
& \text { kan ju visa vad de kan på ett helt annat sätt, jämfört nån som inte kan uttrycka sig. }
\end{aligned}
$$

Therese pekade också på hur yrkesutbildningen kräver att du behärskar svenska. Hon beskrev hur viktigt det var att både förstå vid läsning och att kunna för- 
medla i skriven text. Eftersom kunskaper i svenska är så centrala blir yrkesutbildningen så mycket mer krävande för de personer som inte har svenska som modersmål, än för de som har det.

\begin{abstract}
... Du måste ju lära dig och förstå de här begreppen. Om du inte har svenska som modersmål så har du svårare att komma dit. Sen processa dem på ett annat språk och sen visa att du kan. Det är många fler steg för någon som inte har svenska som modersmål, många fler steg. Som de måste processa för att de ska kunna visa för mig som lärare, för jag kan inte gissa mig fram vad de kan och inte kan. Språk och kunskap hänger så tätt ihop så jag kan inte ens prata om det som olika saker. Det ena förutsätter det andra. Har du inte en bra läsförståelse, förstår du inte en text, så kan inte förstå den, få kunskapen, ha kunskapen, processa den i huvudet så att kunskapen sätter sig. Och även om du har bra läsförståelse, men du har inte tränat på att skriva, du har inte pratat så mycket men du förstår vad det handlar om, det är många som använder, de googlar, de kanske kollar på sina egna modersmăl...
\end{abstract}

Det framstår som att förmedla det talade ordet och den skrivna texten upplevdes som mer centralt och problematiskt i relation till språk och kommunikation inom vård och omsorg än att $t a$ in tal och text. Utifrån intervjuerna med lärare är det således snarare elevernas förmåga att omsätta kunskaper i talade ord och skriven text som är den största utmaningen - inte att eleverna inte alltid förstår i direkt anslutning till undervisning och instruktioner. För att underlätta för elever att ta in tal och text kan lärare - och handledare inom den arbetsplatsförlagda delen av utbildningen - modifiera undervisningen. De kan komplettera muntliga och skriftliga instruktioner med annan typ av kommunikation. Att kunna omsätta kunskap i ord och handling (tala och skriva) är också en form av abstrahering som går bortom förståelsen av direkta instruktioner eller begrepp. Enligt lärarna så förstod eleverna ofta långt mer än vad de kunde uttrycka $i$ text och tal. Att verifiera vad eleverna förstod och inte blev därmed svårt.

\title{
Slutdiskussion
}

Lärarnas roll som gräsrotsbyråkrater - deras uppgift att omtolka och göra praktik av statens intentioner - inom vård- och omsorgsutbildningen påverkas av språkliga hinder. Det gäller inte bara andraspråkstalare, utan också personer med svenska som modersmål. I vår analys har vi gjort en distinktion mellan det skrivna och det talade, och mellan att ta in och förmedla språk. Äldreomsorgen och utbildningar inom vård och omsorg har, som många andra fält, blivit allt mer textbaserade. Kraven på att ta in och förmedla information i text är höga för att kunna genomföra både utbildning och framtida arbete. Att som lärare stå i korsdraget mellan att å ena sidan förse arbetsmarknaden med kompetent personal och å andra sidan skapa en utbildning anpassad till elevernas behov är en utmaning, inte minst som delar av utbildningen är förlagd till arbetsplatsen, en arena där de har begränsade möjligheter att påverka utbildningsvardagen. Lärarnas egna lösningar på dessa problem kan ses som pragmatiska - exempelvis att förenkla språket i läromedel, använda alternativa sätt att kommunicera innebörden 
av fenomen och tona ned regelrätta språkförbistringar som rapporteras från arbetsplatserna. Lösningarna är alla delar av komplexa, ofta personliga strategier lärarna utvecklar för att hantera den press under vilken de befinner sig, med en mängd olika, ofta motstridiga krav. De två mest svårförenliga kraven för de intervjuade lärarna i den här undersökningen var kravet på att individanpassa undervisningen tillräckligt mycket för att samtliga elever skulle kunna tillgodogöra sig utbildningen och samtidigt planenligt examinera färdigutbildade yrkespersoner redo att anställas i vård- och omsorgsyrken. Den springande punkten var att flera elever saknade de språkfärdigheter som krävdes för att kunna uppnå kursmålen. Utbildningsvardagen bestod därför i hög grad av att försöka göra sig förstådd och försäkra sig om att eleverna förstått.

Resultaten är intressanta, kanske framför allt för att de pekar på utmaningarna lärarna inom vård och omsorgssektorn står inför i undervisningsvardagen. Språkets betydelse - och undersköterskors förutsättningar att ta in och förmedla tal och skrift - har med stor sannolikhet blivit ännu mer relevanta efter att materialinsamlingen gjordes. Covid-19 innebar förändrade rutiner och arbetssätt som skulle genomföras under kort tid inom äldreomsorgen. Att de som arbetade med vård av äldre kunde ta till sig tal och skrift, och förmedla tal och skrift, har varit av yttersta vikt för att värna patientsäkerheten. Detta leder också in på frågor om hur språk och kommunikation inverkar på omsorgens kvalitet. Att fördjupa och bredda diskussionen om kopplingen mellan språk, kommunikation och kvalitet i äldreomsorg är ett uppslag för framtida forskning. Lägesbeskrivningen inom äldreomsorgen har varit densamma de senaste två decennierna och kan sammanfattas med att det saknas kompetent personal. Utbrottet av Covid-19 och det faktum att personer som bor på särskilt boende för äldre och personer med hemtjänst har drabbats hårt av viruset, har gjort att den numera väletablerade lägesbeskrivningen fått stor medial uppmärksamhet. Också undervisningsvardagen har givetvis påverkats mycket av Covid-19. Möjligheterna att bedriva undervisning anpassad till varje elevs förutsättningar har kraftigt kringskurits när eleverna förpassats till hemarbete framför dator. Det framstår som extra problematiskt i ljuset av att utvecklingen av distansutbildningen hindrats av bland annat omorganisationer inom skolmyndigheterna på senare tid (SOU 2020:66). När digitalisering av undervisning tillkommer som ytterligare en faktor som präglar utbildningen av undersköterskor är det sannolikt så att betydelsen av elevernas förutsättningar att ta till sig och omsätta det svenska språket accentueras.

\section{Slutnoter}

1 På grund av sin litenhet har vi valt att av avidentifiera den ena kommunen och kort och gott kalla den för "den lilla kommunen".

2 Namnen är fingerade. 
${ }^{3}$ Av dessa fyra lämnade tre återbud. Anledningen till två av återbuden var att de kommunala verksamheterna omorganiserades, vilket innebar nya arbetsvillkor för dem. Det är en metodologisk reflektion som i sig är viktig, eftersom samskapande processer förutsätter långsiktigt relationsbyggande. Tidsperspektiven ser olika ut inom akademin och de kommunala verksamheterna - där de kommunala verksamheterna förefaller mer känsliga för förändringar i omvärlden än vad universiteten gör. Att få till stånd samverkansforskning mellan universitet och kommun bygger i hög utsträckning på personligt engagemang, eftersom det $\mathrm{i}$ allmänhet saknas organisatoriskt stöd för deltagande för kommunalt anställda.

${ }^{4}$ Utredningen för stärkt kvalitet och likvärdighet inom komvux för elever med svenska som andraspråk.

\section{Tack}

Vi vill tacka samhällsvetenskapliga fakulteten vid Göteborgs universitet som finansierat studien genom PAUS-medel. Vi vill också rikta ett stort tack till de lärare som varit delaktiga i forskningsprocessens olika delar.

\section{Om författarna}

Sara Hultqvist är socionom, filosofie doktor i socialt arbete och anställd som lektor på Institutionen för socialt arbete, Göteborgs universitetet. Hon är just nu verksam som postdoktor på Socialhögskolan och CASE, Lunds universitet. Hon undervisar i socialpolitik och på kurser med verksamhetsförlagd utbildning på socionomprogrammet, samt på hälso- och sjukvårdskuratorsprogrammet. Hennes huvudsakliga forskningsområden är arbetsmarknadspolitik, sociala försäkringar och äldreomsorg.

Katarina Hollertz är socionom, filosofie doktor i socialt arbete och anställd som lektor på Institutionen för socialt arbete, Göteborgs universitetet. Hon undervisar på kurser om socialt arbete på samhällsnivå, organisation/ledarskap och på kurser med verksamhetsförlagd utbildning på socionomprogrammet. Hennes huvudsakliga forskningsområden är arbetsmarknadspolitik, styrning i människobehandlande organisationer, professionella roller samt pedagogik i professionsutbildningar. 
"Det är klart de vet vad uppgivenhet betyder"

\section{Referenser}

Andrén, M. (2007). Den europeiska blicken och det lokala självstyrets värden. Gidlunds.

Braun, V. \& Clarke, V. (2012). Thematic Analysis. I H. E. Cooper m.fl. (Red.), APA handbook of research methods in psychology, Vol 2: Research designs. American Psychological Association.

Braun, V. \& Clarke, V. (2020). One size fits all? What counts as quality practice in (reflexive) thematic analysis? Qualitative research in psychology, 1-25.

Brodkin, E. Z. (2011). Policy work: Street-level organizations under new managerialism. Journal of Public Administration Research and Theory, 21(suppl_2), i253i277.

Dahlström, M. \& Gannå, L. (2017). En didaktisk modell för integrering av yrkes- och sfi-undervisning inom YFI-projektet. Stockholms universitet.

Dahlstedt, M. \& Fejes, A. (Red.). (2019). Neoliberalism and market forces in education: Lessons from Sweden. Routledge.

Eliasson, E. \& Rehn, H. (2017). Health and social care teachers' descriptions of challenges in their teaching at upper secondary school. Nordic Journal of Vocational Education and Training, 7(1), 42-63.

Fejes, A. (2019). Redo för komvux? Hur förbereder ämneslärarprogrammen och yrkeslärarprogrammen studenter för arbete i kommunal vuxenutbildning? Linköpings universitet.

Forslund, A. \& Vikström, J. (2011). Arbetsmarknadspolitikens effekter på sysselsättning och arbetslöshet - en översikt. IFAU.

Hamberg, L. (2015). Samverkan i och med språket: Systemisk-funktionell analys av språkanvändning $i$ en kommunal gränsaktivitet med nyanlända flyktingar som målgrupp. Avhandling. Helsingfors Universitet.

Hultqvist, S. \& Hollertz, K. (2019). Lokal arbetsmarknadspolitik med fokus på autonomi och delaktighet. Socialhögskolan, Lunds universitet.

Hultqvist, S. \& Hollertz, K. (2021). Individual need and societal claims. Challenging the understanding of universalism versus selectivism in social policy, Social policy and administration (early view), 1-24.

Hyltenstam, K., Axelsson, M. \& Lindberg, I. (2012). Flerspråkighet: En forskningsöversikt (Vetenskapsrådets rapportserie 5:2012). Vetenskapsrådet.

Jönson, H. \& Szebehely, M. (Red.). (2018). Äldreomsorger i Sverige: Lokala variationer och generella trender. Gleerup.

Lipsky, M. (2010). Street-level bureaucracy: Dilemmas of the individual in public services, 30th anniversary expanded. Russell Sage Foundation.

Norstedt, M. (2011). Berättelser om stroke och arbetsliv: Att upptäcka styranderelationer. [Doktorsavhandling, Lunds universitet]. 
Paul, E. (2017). Skriftbruk som yrkeskunnande i gymnasial lärlingsutbildning: vård-och omsorgselevers möte med det arbetsplatsförlagda lärandets skriftpraktiker. [Doktorsavhandling, Stockholms universitet].

Petersson, J. (2009). Den aktiva arbetsmarknadspolitiken växer fram. I H. Johansson \& I. Hornemann Möller (Red.), Aktivering-arbetsmarknadspolitik och socialt arbete i förändring (s. 87-110). Liber.

Promemoria (2019). På väg - mot stärkt kvalitet och likvärdighet inom komvux för elever med svenska som andraspråk. Utredningen för Stärkt kvalitet och likvärdighet inom komvux för elever med svenska som andraspråk (KLIVA), Regeringskansliet.

Sandwall, K. (2013). Att hantera praktiken: Om sfi-studerandes möjligheter till interaktion och lärande på praktikplatser. [Doktorsavhandling, Göteborgs universitet].

Sarstrand Marekovic, A. M. (2011). Från invandrarbyrå till flyktingmottagning: fyrtio års arbete med invandrare och flyktingar på kommunal nivå. [Doktorsavhandling, Linnéuniversitetet]. Arkiv förlag.

SCB. (22 april 2020a). Kommuner i siffror: Tabeller och fördjupning. https:/ / www.scb.se/hitta-statistik/sverige-i-siffror/kommuner-i-siffror/\#?region1=0763\&region2=1480

SCB. (22 juli 2020b). Yrken i Sverige. https://www.scb.se/hitta-statistik/sverigei-siffror/utbildning-jobb-och-pengar/yrken-i-sverige/

Skolverket. (2019). Elever, kursdeltagare och studieresultat $i$ grundläggande och gymnasial vuxenutbildning år 2018 (PM Dnr: 2018:01723). https://www.skolverket.se/getFile?file $=4391$

Skolverket. (23 juli 2020). https://www.skolverket.se/skolutveckling/statistik/sok-statistik-om-forskola-skola-och-vuxenutbildning?sok=SokC\&verkform $=$ Komvux \% 20exklusive \%20sfi\&omrade=Elever\%20och\%20kursdeltagare\&lasar $=2018 \&$ run=1

Smith, D. E. (2005). Institutional ethnography: A sociology for people. AltaMira Press.

Socialstyrelsen. (2004). Investera nu! Handlingsplan för kompetensförsörjning inom vård och omsorg. Socialstyrelsen.

SOU. (2017:21). Läs mig! Nationell kvalitetsplan för vård och omsorg om äldre personer. Wolters Kluwer.

SOU. (2019:20). Reglering av yrket undersköterska, Stärkt kompetens i vård och omsorg. Norstedts Juridik.

SOU. (2019:69). Validering - för kompetensförsörjning och livslångt lärande. Norstedts Juridik.

SOU. (2020:66). Samverkande krafter - för stärkt kvalitet och likvärdighet inom komvux för elever med svenska som andraspråk, Betänkande av KLIVA-utredningen. Norstedts Juridik.

Storm, P. (2018). Betydelsen av kön och hudfärg i äldreboendets vardag under olika organisatoriska villkor. Stockholms universitet. 
Weinar, A., Bonjour, S. \& Zhyznomirska, L. (Red.). (2018). The Routledge handbook of the politics of migration in Europe. Routledge.

Weatherly, R. \& Lipsky, M. (1977). Street level bureaucrats and institutional innovation: Implementing special-education reform, Harvard Educational Review, 47(2), 171-97.

Wärvik, G. B. \& Lindberg, V. (2018). Integration between school and work: Changes and challenges in the Swedish VET 1970-2011. I Choy, S., Wärvik, G. B. \& Lindberg, V. (Red.), Integration of vocational education and training experiences: Purposes, practices and principles (s. 279-301). Springer. 